\title{
Structures within the surge front at Bakaninbreen, Svalbard, using ground-penetrating radar
}

\author{
Tavi Murray, ${ }^{1}$ Daniel L. Gooch, ${ }^{2}$ Graham W. Stuart ${ }^{2}$ \\ ${ }^{1}$ School of Geography, University of Leeds, Leeds, West Yorkshire LS2 9JT, England \\ ${ }^{2}$ Department of Earth Sciences, University of Leeds, Leeds, West Yorkshire LS2 9J7, England
}

\begin{abstract}
Bakaninbreen, Svalbard, started to surge during 1985-86, and developed a surge front up to $60 \mathrm{~m}$ high. Associated with down-glacier propagation of this surge front was the formation of shear zones and thrust faults, some of which revealed basally derived debris at the glacier surface. Hot water drilling and sampling of basal material showed the glacier bed to be soft sediment more than $1 \mathrm{~m}$ thick. A high-resolution ground-penetrating radar (GPR) survey at $100 \mathrm{MHz}$ was conducted along three $500 \mathrm{~m}$ lines parallel to glacier flow on the surge front. The aims were to investigate the internal geometry of the thrust features, and the processes of entrainment of basal debris into bulk glacier ice.

A strong linear reflector was seen on the survey, but it is about 15-20 $\mathrm{m}$ above the bed as identified from drilling depths. It probably represents the upper interface of a layer of debris-rich basal ice. Several extensive englacial reflectors were interpreted as debris-laden emergent thrust features, varying in thickness from 0.1 to $1.1 \mathrm{~m}$. These features were mapped at the glacier surface, and drilling and sediment sampling verified the interpretation. Other englacial features included regions of incipient thrusting at the basal reflector, and an extensive region of scattering up to $30 \mathrm{~m}$ above the basal reflector that we interpret as folds, or blind thrusts that terminate englacially. Our results clearly demonstrate the potential of GPR for mapping internal glacial structure, and suggest that thrusting is an important process by which sediment is incorporated into glacier ice in the highly compressive region at the surge front.
\end{abstract}

\section{INTRODUCTION}

Bakaninbreen is a $17 \mathrm{~km}$ long surge-type glacier situated at the head of Van Mijenfjorden in southeast Spitsbergen, Svalbard. The glacier started surging between the springs of 1985 and 1986, and developed a steep surge front up to $60 \mathrm{~m}$ high where the fast-flowing surging ice met the inactive ice. This surge front propagated down-glacier at rates of up to $2 \mathrm{~km}$ year $^{-1}$, the rate of propagation slowing during 1990 and subsequent years (Dowdeswell and others, 1991). By 1994-95 the surge front had effectively ceased propagation about $1.8 \mathrm{~km}$ from the glacier margin, but still formed a steep ramp $50-60 \mathrm{~m}$ high at the glacier surface.

The passage of the surge front has been associated with a wave of compression and extension travelling down-glacier, similar to that described during the 1982-83 surge of Variegated Glacier, Alaska, U.S.A, by Sharp and others (1988). The glacier surface in the upper part of Bakaninbreen was lowered by several metres, resulting in stranded ice blocks on the valley walls, whereas in the lower part of the glacier the ice has been compressed and uplifted. Associated with this compression, high-angled shear zones and thrust features have developed, some of which are associated with outcropping debris dykes. A structural glaciological survey showed the modal up-glacier dip of the thrusts to be $70-80^{\circ}$, and that the debris within the features originated from the glacier bed (Hambrey and others, 1996).

Thrusting is commonly reported as a marginal phenomenon on glaciers with cold-based ice at their termini (e.g.
Hambrey, 1994). However, thrusting in thick ice where sediments are reported to reach the glacier surface appears to be limited to surge-type glaciers. During the surge of Variegated Glacier, thrusting was observed at the surface below the surge front (Kamb and others, 1985; Lawson and others, 1994). At surge-type Trapridge Glacier, Yukon Territory, Canada, Clarke and Blake (1991) used borehole depths to infer the presence of a sediment-filled blind-thrust fault forming during quiescence.

As part of a major programme of research on Bakaninbreen (Murray and Porter, 1994; Hambrey and others, 1996; Porter and others, 1997), a ground-penetrating radar (GPR) survey was undertaken during 1995 along three lines on the surge front. The aims of the survey were threefold: to assess commercial GPR as a means for determining glacial structure in relatively deep ice; to investigate the internal geometry of outcropping thrust faults; to identify any blindthrust faults, and therefore to assess the role of thrusting in the incorporation of basal debris into bulk glacier ice. A structural survey of features evident at the glacier surface together with extensive hot water drilling and sediment sampling from the glacier bed and from internal thrust features allowed confirmation of features identified by geophysical means.

GPR is a relatively new geophysical technique for determining shallow subsurface structure in geologic materials such as sediments and rock. GPR uses electromagnetic radiation in the radio frequency band $(10-1000 \mathrm{MHz})$. The velocity and attenuation of this radiation depends on the 
complex permittivity of the material, and the signal is reflected at boundaries across which this property changes (Davis and Annan, 1989). For most materials the water content is the most significant factor controlling this electrical property. Because ice has a very low conductivity it is a very low-loss medium, and significant depths of penetration can be achieved.

The traditional glaciological use of radar has been for depth sounding, and on Svalbard several programmes have been undertaken for this purpose (e.g. Macheret and Zhuralev, 1982; Dowdeswell and others, 1984; Hagen and Sætrang, 1991). However, this technique is limited in its ability to resolve englacial structure, particularly on temperate or polythermal glaciers, because of the loss of signal strength due to scattering (Arcone and others, 1995). Radio-echo sounding uses a frequency envelope containing many cycles typically of $10-65 \mathrm{MHz}$. Impulse radars, including most modern GPR systems, greatly reduce scattering since they use a shorter wave packet, normally one-anda-half cycles (Arcone and others, 1995). Early systems developed in the 1980s were of low resolution, using frequencies typically below $20 \mathrm{MHz}$ (Arcone and others, 1995). Despite this, some studies reported large-scale englacial structures such as water-filled channels or voids, for example on Variegated Glacier (Jacobel and Raymond, 1984; Jacobel and Anderson, 1987) and on Storglaciären, Sweden (Kennett, 1989; Walford and Kennett, 1989), and Bamber (1988) used similar features in his explanation of internal reflecting horizons in some Svalbard glaciers.

Recent advances in commercial GPR have enabled the use of much shorter wavelengths than were used in earlier impulse radars, and therefore higher-resolution surveys can be achieved, especially in ice where high frequencies are not attenuated. High-resolution studies using GPR have shown the ability of the technique to delineate the upper boundary of basal ice (Arcone and others, 1995) and determine glacier depth (Nicollin and Kogman, 1994; Nobes and others, 1994), but little has been published as yet on englacial structure using GPR.

\section{FIELD SITE}

The glacier Bakaninbreen $\left(77^{\circ} 45^{\prime} \mathrm{N}, 17^{\circ} 15^{\prime} \mathrm{E}\right)$ flows southwest for $9 \mathrm{~km}$ and is then forced round an approximately $90^{\circ}$ bend at its confluence with the glacier Paulabreen (Fig. 1). It then flows northwest up to its margin which constitutes a grounded ice cliff at the fjord head. The glacier is considered to be polythermal, in common with most large glaciers in Svalbard (Hambrey and others, 1996). In 1995 the surge front affected about $300 \mathrm{~m}$ of the longitudinal profile of the glacier, and extended right across Bakaninbreen, which is approximately $1.0 \mathrm{~km}$ wide at this point. The surge front is a ramp of ice approximately $60 \mathrm{~m}$ high, and greatly increases local ice slope. The overall average glacier slope of $1: 300$ rises to an average of $1: 5$ on the surge front, the steepest parts being 1:4 (Gooch, 1995). Both the velocity and the longitudinal profile of Paulabreen appear to have been completely unaffected by the surge of Bakaninbreen.

Hot water drilling has shown that Bakaninbreen overlies soft sediments at least $1 \mathrm{~m}$ thick in the region of the surge front (Murray and Porter, 1994). These probably consist of a mix of glacial till and marine fjord sediments (Hambrey and others, 1996). Underlying these sediments the bedrock

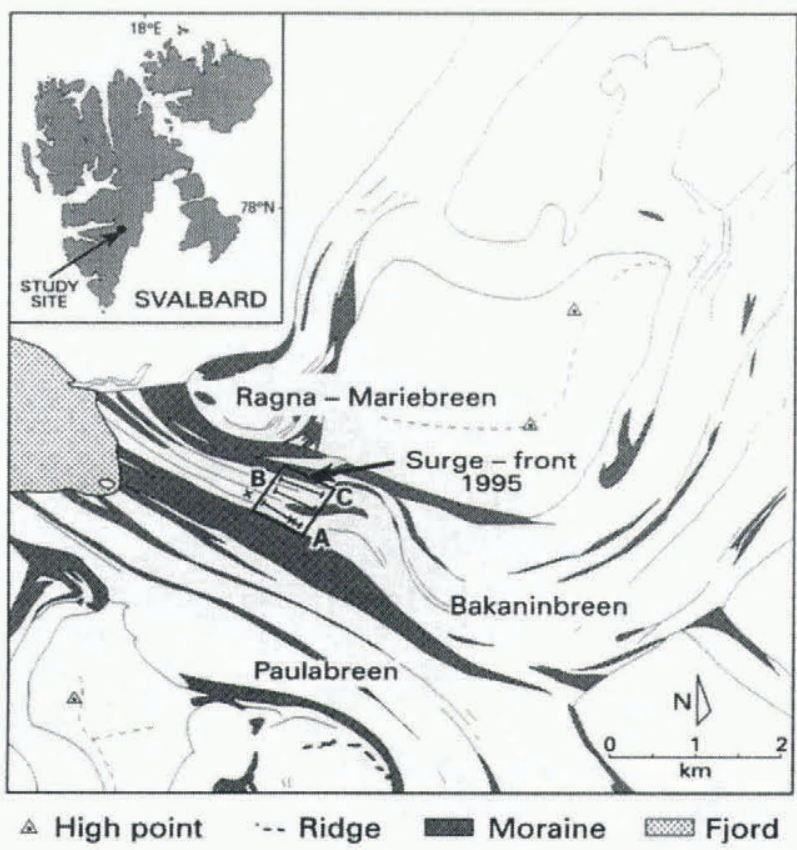

Fig. 1. Map showing study site on Bakaninbreen, southeast Svalbard, and position of GPR survey lines on the surge front. Four CMP surveys were conducted, centred at two locations on line A, one above and one below the surge front. At each location, one survey was done parallel and one perpendicular to ice-flow direction. The two centres of the CMP surveys are shown by crosses.

consists of sedimentary sandstone and mudstone, with structural strata dipping at a low angle (usually less than $15^{\circ}$ ) to the west-southwest (Salvigsen and Winsnes, 1987). There is a considerable amount of debris on the glacier surface, which results from both melting-out debris dykes and supraglacial sources (Hambrey and others, 1996).

\section{DATA COLLEGTION}

The radar used in this study was a PulseEKKO 100 GPR made by Sensors and Software Inc., Mississauga, Canada, equipped with $100 \mathrm{MHz}$ resistively loaded dipole antennae. The energy transmitted by this type of antennae is directional, with most power directed downwards in a plane perpendicular to the long axis of the antenna (Annan and others, 1975). Therefore, our surveys were undertaken with the antennae orientated perpendicular to the line of survey so that maximum power is transmitted in-line. In this way reflections from off-line are minimised, although it is still possible for high-conductivity surface features, such as survey poles, data loggers or streams, to produce reflections.

Two types of survey were undertaken: (1) surveys with a constant offset $(\mathrm{CO})$ between the transmitting and the receiving antenna, and (2) common midpoint (CMP) surveys. During $\mathrm{CO}$ surveys the antennae were fixed at a separation of $1.17 \mathrm{~m}$, and the GPR system was mounted on two small sledges. In addition to the major CO surveys, four CMP surveys were performed on line A. This type of survey allows calculation of the velocity of propagation to major reflectors, and therefore correct interpretation of the depth to features recorded on $\mathrm{CO}$ lines. The CMP surveys were performed in pairs parallel and perpendicular to ice flow, one pair situated above and one below the surge front (Fig. 1), in order to investigate possible velocity anisotropy. CMP 
surveys require that the distance between the antennae be varied, and the antennae had to be unmounted from their sledge and moved by hand.

The GPR system was set up to stack 64 traces per transmitter and receiver position, and to record for $2048 \mathrm{~ns}$. This time window was the maximum available on the Pulse EKKO software, and represents a glacier thickness of about $170 \mathrm{~m}$, somewhat greater than our drilling programme suggests for ice in the vicinity of the surge front on Bakaninbreen. Data were collected using a sampling interval of $1600 \mathrm{ps}$ as recommended by Sensors and Software (1994).

Three survey lines, A, B and C, were laid out on the major flow units of Bakaninbreen (Fig. 1), using a $100 \mathrm{~m}$ tape and sighting compass, and marked using cairns at intervals of $50 \mathrm{~m}$. These markers were later surveyed to allow topographic correction of the GPR data. Readings were taken at a station spacing of $0.5 \mathrm{~m}( \pm 0.05 \mathrm{~m})$ on each line. This mode of operation (stop-and-collect) is more labour-intensive than a continuous profiling mode (e.g. Arcone and others, 1995), but the survey thus avoids the degradation that can result from movement of the system and poor coupling between the antennae and surface during continuous profiling. Further, a stop-and-collect survey provides increased locational accuracy when the survey results are compared with known surface features. All three lines show similar features; due to space limitations we discuss only line A in this paper.

Other work on the glacier includes borehole drilling and instrumentation of the glacier bed. As a result there are wires running across the glacier surface and to the bed, as well as data loggers in some locations. During the survey, structural features such as shear zones or thrust features were noted, as well as the location of external sources of system noise such as streams, sediment, or surface wiring on or close to the survey lines. All surveys were undertaken in the ablation zone during August 1995; surface melting was occurring on the glacier, and several supraglacial streams were crossed by the survey lines.

\section{DATA PROCESSING}

Data were processed in two phases: initial processing used the PulseEKKO software prior to importing the data into the ProMAX seismic processing software (Advance Geophysical Coporation) which allowed detailed processing, parameter testing, migration and higher-quality output. Initial processing proceeded in four stages: trace editing to remove repeated traces or to interpolate a missed trace; application of a dewow filter to remove low-frequency noise resulting from outside radio sources or instrument drift; zero-time adjustment to compensate for instrument drift; and finally conversion to SEG-Y format. Once these data were in SEG-Y format they could be input into ProMAX, although rescaling of both the time and the distance axes was required to bring them into the allowed ranges for seismic data. Within ProMAX an automatic gain control (AGC) function with time window $400 \mathrm{~ns}$ was used to correct for geometrical spreading and attenuation within the ice to $1000 \mathrm{~ns}$, below which a constant gain function was used. The data were filtered using an optimized bandpass algorithm with bandpass flat between 75 and $135 \mathrm{MHz}$ and half power points at 35 and $180 \mathrm{MHz}$. Elevation statics were applied to the lines to correct for topographic variations up the surge front. Migration using constant-velocity Stolt F-K and Kirchoff algorithms was used to clarify structure and to place reflectors in their correct geometric position. In all cases a velocity of $0.167 \mathrm{~m} \mathrm{~ns}^{-1}$ was used, compatible with velocity analysis on CMP data.

\section{RESULTS}

Analyses of data collected from CMP surveys provide an estimate of the velocity of the radar signal. With the Pulse EKKO system used, the maximum separation that can be achieved between transmitter and receiver is limited by the length of the optical cables that link them to the control console $(40 \mathrm{~m})$. This surface separation then limits the change in travel distance to reflectors, and together with picking errors determines the uncertainty in the calculated velocity. The velocity calculated to the basal reflector varied from 0.163 to $0.173 \pm 0.025 \mathrm{~m} \mathrm{~ns}^{-1}$. The relatively large error is primarily caused by the small change in move-out of the reflectors at depth. In our analyses we have assumed a constant velocity of propagation through the glacier of $0.167 \mathrm{~m} \mathrm{~ns}^{-1}$. Although the velocity of propagation through ice varies with density, impurity content and temperature, the review of Bogorodsky and others (1985) places almost all measurements in the range $0.167-0.177 \mathrm{~m} \mathrm{~ns}^{-1}$, within $6 \%$ of our assumed velocity.

Figure 2 shows the GPR output from the constant offset survey on line A. The upper panel shows the survey data with no filtering or topographic correction, and marks the position of major surface features likely to cause interference. The lower panel shows data with elevation statics and filtering applied. The main features are as follows.

\section{Surface features and artefacts}

Several features on the lines can be ascribed to surface features, side reflections or interference (Fig. 2a); it is important to the interpretation that such artefacts be identified. Examples of the type of interference caused by surface streams can be seen on line A near $100 \mathrm{~m}$. Two traces are dead at 238 and $238.5 \mathrm{~m}$ as a result of radio transmission from a hand-held VHF radio. Reflections from offline features are minimised by orientation of the antennae, and offline sources such as wiring produce diffraction patterns with a curvature characteristic of their distance offline and known velocity of the GPR signal in air and ice; for example, uniform diffraction patterns seen at $450 \mathrm{~m}$ on line $\mathrm{A}$ are due to wiring and a data logger approximately $20 \mathrm{~m}$ from the line.

\section{Basal reflector}

A strong linear reflector seen on all survey lines dips gently down-glacier towards the fjord head ( $\mathrm{B}$ in Figure $2 \mathrm{~b}$ ). This reflector is typically composed of one distinct reflector, with many diffraction patterns originating from it or crossing it. The depth of this reflector varies from 48 to $112 \mathrm{~m}$. Below the reflector a series of steeply up-glacier dipping reflections or diffractions are seen.

\section{Basal region}

Each line shows regions where a large number of diffraction hyperbolae occur, situated about $20-30 \mathrm{~m}$ above the main basal reflector. We term these regions the scattering layer. 

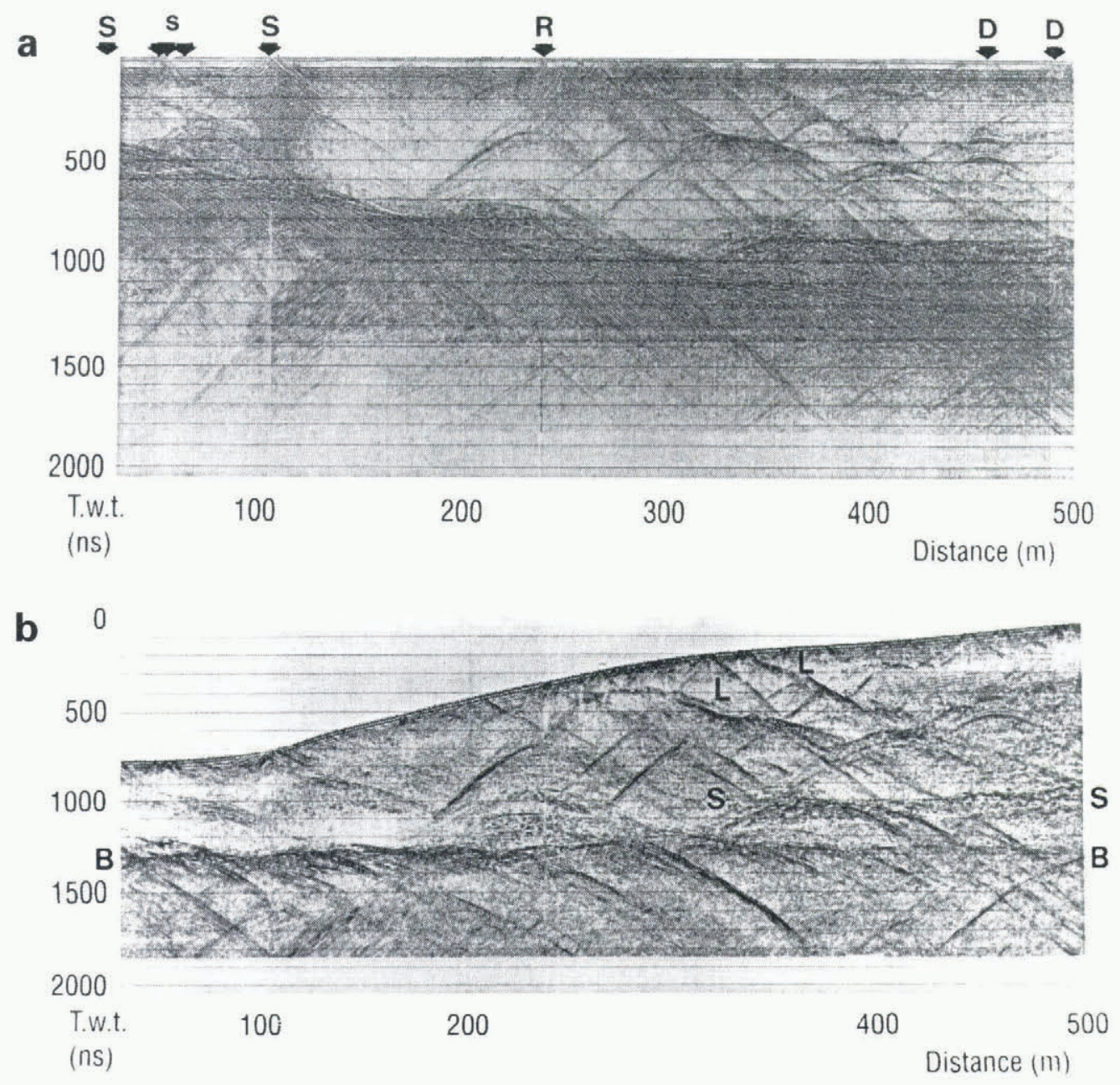

Fig. 2. GPR output from line A, processed using an AGC function to 1000 ns and a constant gain function below this. In each case the lefthand axis is a two-way travel time. (a) Survey data without static correction or filtering applied, showing the position of major surface features likely to cause interference: $S$, stream; $s$, small streams; $D$, data logger, tripod or wiring; $R$, radio transmission. (b) Data after application of elevation statics and filtering. The figure is shown with no vertical exaggeration, so that the profile is the true surface profile of the ice surface. Labelled features are: L, dipping reflectors (enlarged in Figure 4); B, basal reflector (enlarged in Figure 5); $S$, top of scattering layer. Details of the gain function and filter used are given in the text.

\begin{abstract}
On line A the scattering layer is seen in two regions, situated at $160-260 \mathrm{~m}$ and $310-500 \mathrm{~m}$ ( $\mathrm{S}$ in Figure $2 \mathrm{~b}$ ). Many of the diffractions in this region have asymmetric amplitudes, and therefore cannot result from point reflectors.
\end{abstract}

\section{Structures within the surge front}

Two relatively strong reflectors are seen on line A between about 250 and $400 \mathrm{~m}$ ( $\mathrm{L}$ in Figure 2b). The reflectors dip up-glacier, but the continuity of these features is hard to ascertain on the unprocessed section due to the presence of numerous diffraction patterns. The majority of diffraction patterns are asymmetric and originate on or near these features.

\section{EVIDENGE ON THE NATURE OF REFLECTORS}

In this section we use evidence from the GPR survey together with results from hot water drilling and sediment sampling to infer the characteristics of the various reflectors described above.

\section{Borehole drilling and sampling}

Boreholes were drilled at a number of locations on the GPR survey lines, and at each location the depth at which drilling terminated was noted; typically this depth is assumed to be the glacier bed. However, the depth at which drilling ceased varied (Table 1), and a number of these holes are assumed to have failed to reach the bed, although hot water was kept running into the hole for up to $1 \mathrm{~h}$ after downward motion first ceased. Fine or dispersed debris is unlikely to slow the drill significantly, as this material can be flushed from the hole. Similarly, individual large clasts are unlikely to stop the drill, as a cavity will be created that allows the drill to pass the obstruction. It is most likely that the drill is stopped by significant thicknesses of sediment that include sufficient coarse material to make the spray of the drill too diffuse to continue to melt a hole into the ice.

When the drill was retrieved from some boreholes, sediment was stuck to the drill stem and hose, and so could be sampled. In 1995 we used a specially designed sampler to collect samples from the base of some holes. In this way we can firmly identify some of the reflectors as originating from sediment layers or inclusions. 
Table 1. Depths ( $m$ ) of boreholes on or close to radar lines. Borehole depths are considered accurate to $\pm 1 \mathrm{~m}$, and reflector depths to $\pm 2 \mathrm{~m}$

\begin{tabular}{|c|c|c|c|c|}
\hline Distance along GPR survey & \multirow[t]{2}{*}{ Borehole } & \multirow{2}{*}{$\begin{array}{c}\text { Borehole } \\
\text { depth } \\
\text { m }\end{array}$} & \multirow{2}{*}{$\begin{array}{c}\text { Depth top } \\
\text { scattering } \\
\text { layer } \\
\text { m }\end{array}$} & \multirow{2}{*}{$\begin{array}{c}\text { Depth basal } \\
\text { reflector } \\
\text { m }\end{array}$} \\
\hline $\mathrm{m}$ & & & & \\
\hline \multicolumn{5}{|l|}{ Line A } \\
\hline \multirow[t]{5}{*}{400} & $95 \mathrm{H} 36$ & 78 & 78 & 98 \\
\hline & $95 \mathrm{H} 29$ & 100 & & \\
\hline & $95 \mathrm{H} 27$ & 101 & & \\
\hline & $95 \mathrm{H} 30$ & 103 & & \\
\hline & $95 \mathrm{H} 27 \mathrm{R}$ & 116 & & \\
\hline \multirow[t]{8}{*}{460} & $94 \mathrm{H} 34 \mathrm{R}$ & 90 & 78 & 105 \\
\hline & 94H31 & 103 & & \\
\hline & 94H35 & 105 & & \\
\hline & 94H32 & 111 & & \\
\hline & $94 \mathrm{H} 25$ & 114 & & \\
\hline & $94 \mathrm{H} 26$ & 114 & & \\
\hline & 94H33 & 121 & & \\
\hline & 94H34 & 121 & & \\
\hline \multirow[t]{4}{*}{500} & 95H09 & 54 & 78 & 111 \\
\hline & $95 \mathrm{H} 08$ & 113 & & \\
\hline & $95 \mathrm{Hl} 0$ & 116 & & \\
\hline & $95 \mathrm{Hl} 4$ & 129 & & \\
\hline \multicolumn{5}{|l|}{ Line B } \\
\hline \multirow[t]{4}{*}{0} & $95 \mathrm{H} 45$ & 54 & 45 & 56 \\
\hline & $95 \mathrm{H} 49$ & 59 & & \\
\hline & $95 \mathrm{H} 46$ & 74 & & \\
\hline & $95 \mathrm{H} 50$ & 75 & & \\
\hline
\end{tabular}

\section{Analysis of phase}

If the propagating GPR signal encounters a change in electrical properties, the signal is partially reflected at the boundary and partially transmitted beyond it. The ratio of reflected to incident energy, and phase of the reflected signal are controlled by the reflection coefficient at the boundary. This coefficient is in turn dependent on the dielectric coefficients above and below the interface (Table 2).

In order to detect a phase shift, the phase of the transmitted wave must be established and used as a reference. This procedure is carried out in a similar manner to that

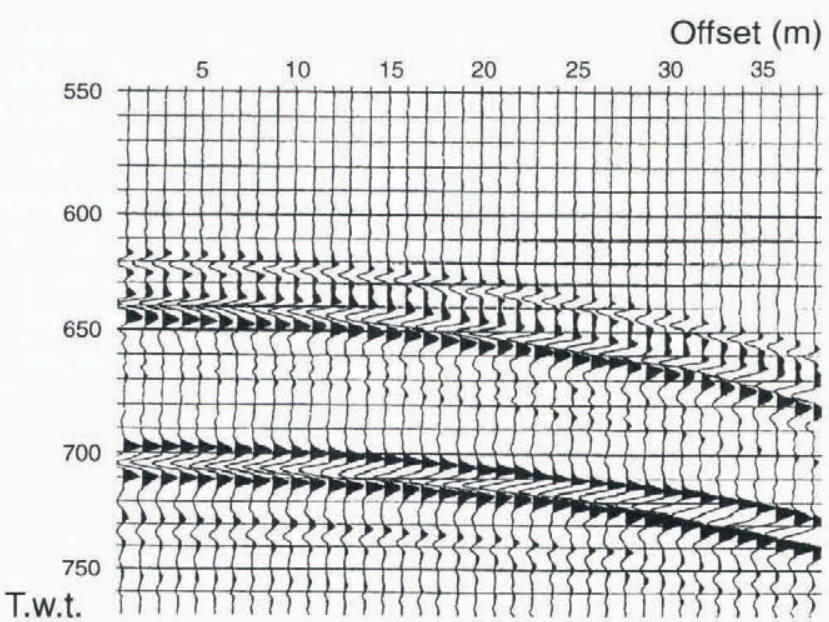

(ns)

Fig. 3. Section of CMP survey performed down-glacier on line $A$. The lefthand axis is a two-way travel time. Three reflectors can be seen, and each has a peak-trough-peak appearance as does the direct airwave.
Table 2. Dielectric coefficients for some typical subglacial materials

\begin{tabular}{lcl}
\hline \multicolumn{1}{c}{ Material } & $\begin{array}{c}\text { Dielectric } \\
\text { coefficient }\end{array}$ & \multicolumn{1}{c}{ Source } \\
& 1 & Davis and Annan (1989) \\
Air & $3-4$ & Davis and Annan (1989) \\
Ice & 80 & Davis and Annan (1989) \\
Water & $5-15$ & Davis and Annan (1989) \\
Sedimentary sand and & & \\
$\quad$ mudstones & 12 & Jones (1987) \\
Till (porosity $=0.15)$ & 18 & Jones (1987) \\
Till (porosity $=0.3)$ & 6 & Jones (1987) \\
Sediment-rich ice & & \\
& & \\
\hline
\end{tabular}

reported by Arcone and others (1995). Using the results from a CMP survey, the two direct waves (airwave and ice wave) can be distinguished once the antenna separation exceeds $6 \mathrm{~m}$. The transmitted airwave, the first arrival, has a peaktrough-peak appearance. Below this, three reflection events can be seen (Fig. 3). Each of these reflection events has a waveform of the same form (peak-trough-peak) as the direct airwave. The reflection coefficient across the first interface is likely to be negative, since ice has a lower dielectric coefficient than most materials that would cause this reflection (Table 2). Hence, we can conclude that a reflection with the same waveform as the direct wave results from an interface with a negative reflection coefficient. This conclusion is the same as that found for $400 \mathrm{MHz}$ antennae by Arcone and others (1995).

\section{Imaging of dipping layers}

The concentration of diffraction patterns seen on line A between 250 and $400 \mathrm{~m}$ results from one or possibly two dipping layers within the glacier. Figure 4 a shows an enlargement of the two reflectors after migration at a constant velocity using an $80 \%$ velocity scaling factor. The visible part of this reflector extends for approximately $70 \mathrm{~m}$ from a position $15 \mathrm{~m}$ below the surface at position $297 \mathrm{~m}$, to a depth of approximately $45 \mathrm{~m}$ at position $362 \mathrm{~m}$, giving an average up-glacier dip of $15^{\circ}$. The reflector is intermittent, with sections varying in length from 2 to $10 \mathrm{~m}$ separated by gaps of similar length. A thin line of sediment associated with a thrust feature was seen at the glacier surface at the position where this reflector would meet the surface if it were extended upwards. The up-glacier of the two reflectors is somewhat weaker, but is still clearly apparent in the data for a distance of approximately $60 \mathrm{~m}$. This reflector has an up-glacier dip of approximately $20^{\circ}$.

The down-glacier reflector shows three distinct waveforms (Fig. 4b): first, a peak-trough-peak-trough pattern (e.g. trace 623); secondly, a simple peak-trough-peak pattern (e.g. trace 576); and thirdly, a very weak or absent pattern (e.g. trace 648). The initial peak-trough-peak represents reflection at an interface with a negative reflection coefficient, as would be caused by, for example, a transition from ice to sediment, or ice to sediment-rich ice (Table 2). A second reflection of the opposite phase would be expected from the base of the layer, provided that the thickness of the layer was not less than the resolution of the radar waves. If the layer has a thickness equal to half the wavelength, $\lambda$, then the two reflections will interfere con- 
a

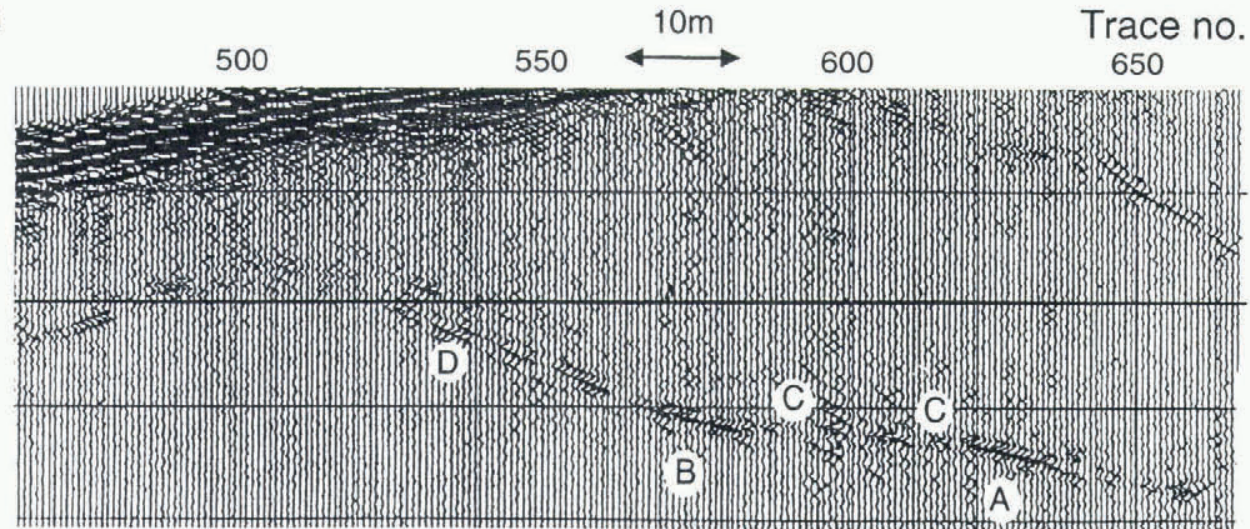

b T.w.t.

(ns) 648576623

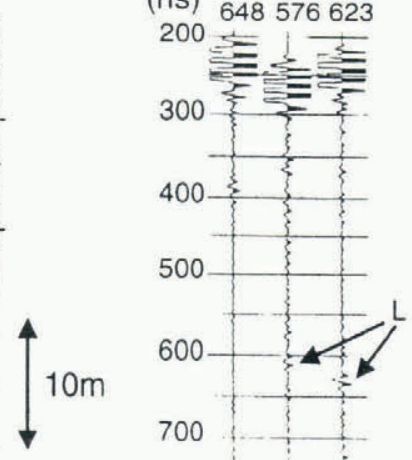

Fig. 4. (a) Migrated and enlarged section of line A from 250 to $400 \mathrm{~m}$ showing major shallow dipping reflector interpreted as a sediment thrust feature. The layer thickness is approximately $1.1 \mathrm{~m}$ at $\mathrm{A}$, approximately $0.55 \mathrm{~m}$ at $\mathrm{B}$ and less than $0.1 \mathrm{~m}$ at $C$. Events at $D$ are due to unmigrated diffraction patterns. (b) Enlargement of individual reflections from trace numbers 648,576 and 623. Layer reflections are labelled $L$. These reflections allow the thickness of the layer to be estimated (see text for details).

structively, and the waveform seen will be peak-troughpeak-trough as in the first case. In ice at $100 \mathrm{MHz}$ frequency this layer thickness is $1.10 \pm 0.24 \mathrm{~m}$. If the layer has a thickness of $\lambda / 4$, only one reflector will be visible, and the resulting waveform will be as described in the second case above. This thickness is $0.55 \pm 0.12 \mathrm{~m}$. In the case of a layer thinner than approximately $\lambda / 30$ the reflections from the top and base of the layer will destructively interfere, and little or no reflection will be seen. This destructive interference will occur for a layer $0.07 \pm 0.02 \mathrm{~m}$ thick. This layer therefore varies in thickness, with visible sections 0.55 $1.1 \mathrm{~m}$ thick.

The sediment layer outcropping at the glacier surface was approximately $0.1 \mathrm{~m}$ thick, which is very close to the detection limit for a layer and would probably not be seen as an event. This is consistent with the reflection events seen in Figure $4 \mathrm{a}$, which do not extend to the glacier surface. We conclude that this reflector consists of a layer of sediment or sediment-rich ice varying in thickness from 1.1 to $0.55 \mathrm{~m}$ where the reflector is visible, to $0-0.1 \mathrm{~m}$ where it is missing. We suggest that the layer may have been formed by the incorporation of basal material into englacial positions along thrust faults in a similar manner to that proposed by Hambrey and others (1996).

\section{Basal region}

The depth of the major basal reflector calculated from the radar survey is at all locations less than the depth measured from the deepest borehole by some 15-20 m (Table 1). Boreholes are never straight, but it is unlikely that deviation from vertical could cause this scale of effect, as the angle of drilling would have to differ greatly from vertical (by $20-30^{\circ}$ ). Similarly, it is unlikely that the effect is due to tortuosity of the borehole, or that the velocity of the radar waves in ice differs by the required $15-40 \%$ from the velocity used. Thus we believe that the radar reflector and the level at which our deepest boreholes are finished are not the same. One possibility is that we drill into the soft sedimentary bed to some considerable depth; the sediment that sometimes collects on the hose and drill stem might suggest that this occurs. However, it is unlikely that we drill to this depth into basal sediment, because if so the englacial layers stopping the drill would need to be of similar thickness. Furthermore, an upper limit on the depth to which drillholes can penetrate the bed is given by our ploughmeters, which must have their upper part trapped in the ice to register a signal (Fischer and Clarke, 1994; Porter and others, 1997). These instruments are $2 \mathrm{~m}$ long. We therefore believe that the basal reflector seen on the GPR traces is a reflector sub-parallel to the base of the glacier. The reflector could result from a thermal boundary (e.g. Björnsson and others, 1996), but no such boundaries have been reported in Svalbard in ice as thin as that occurring below the surge front at Bakaninbreen, and the ice is expected to be cold-based in this region. Thermistors situated above the surge front suggest that the basal temperature approaches the pressure-melting point, but the thermal regime at the surge front is unknown. However, our drill stopped at the depth of the basal reflector in several boreholes (Table 1), which requires significant sediment incorporation in this layer. In those holes that successfully reach the bed of the glacier as indicated by instrumentation (Porter and others, 1997), extremely turbid outflow occurred once drilling had reached the approxi-

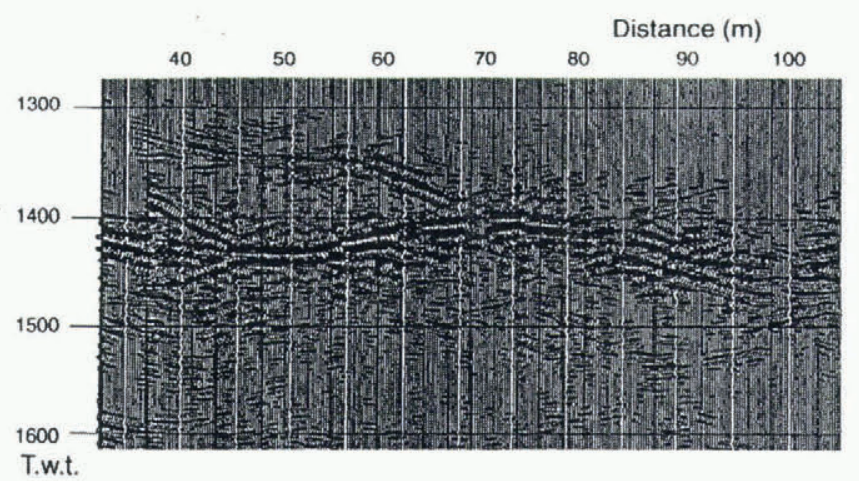

(ns)

Fig. 5. Enlarged section of basal reflector. The lefthand axis is a two-way travel time. The prominent reflector is interpreted as the upper surface of a sediment-rich basal ice layer. The upper surface of the layer consists of short sections about $5 \mathrm{~m}$ long and short steps about $1 \mathrm{~m}$ high. This geometry probably results from folding or faulting at the upper surface. The dipping reflector is interpreted as a fold in the upper interface of the basal ice or a blind-thrust feature that fails to reach the glacier surface. 
mate depth of this reflector. We therefore interpret this reflector to be the upper interface of a layer of sediment-rich basal ice some 15-20 $\mathrm{m}$ thick.

The basal reflector is associated with strongly up-glacier dipping reflections or diffractions (Fig. 2). These features are not associated with bedrock strata which are dipping essentially cross-glacier at right-angles to the radar lines. Figure 5 shows an enlarged section of the basal reflector from 32.5$82.5 \mathrm{~m}$ at a depth of $53 \pm 2 \mathrm{~m}$ after migration. The main reflector is composed of short sections of approximately $5 \mathrm{~m}$ separated by vertical steps of less than $1 \mathrm{~m}$. The dipping reflectors have been successfully migrated, and probably are artefacts of a non-uniform upper surface to the basal reflector. The phase of the reflection indicates a change from low to high dielectric coefficient which would be consistent with a reflection from sediment-rich ice or sediment (Table 2). This stepped geometry could result from folding or faulting of the upper surface of the basal ice. Also visible in Figure 5 is a dipping reflector that rises from the upper interface of the basal reflector. The major dipping reflector seen is approximately $30 \mathrm{~m}$ long and rises at an angle of about $24^{\circ}$ from the basal reflector. The phase of the reflection from this feature suggests that the layer is of sediment or sedimentrich ice, and that it is approximately $1.1 \mathrm{~m}$ thick. We interpret this, and other similar features, as a fold or a blind thrust that fails to reach the ice surface. All of these features are consistent with an overall compressive regime in this region of the glacier.

At Variegated Glacier, basal ice thicknesses are reported to be $1.5-15 \mathrm{~m}$, varying with the degree of longitudinal shortening resulting from compression (Sharp and others, 1994). On Bakaninbreen many boreholes (25 out of 6l) failed to reach the bed above the surge front, but below it only very few boreholes ( 4 out of 36 ) failed to reach the bed. Furthermore, above the surge front, boreholes spaced very close together are completed at different depths (Table 1). The contrast in horizontal compression across the surge front is large because the vertical uplift of approximately $100 \%$ associated with the formation of the surge front results largely from horizontal shortening. It is thus likely that the thickness of basal ice is greater above than below the surge front, and that folding and thrusting is intense in the region above the surge front so that the position and concentration of sediment in the glacier ice varies over a short distance, causing boreholes to terminate at different depths below the glacier surface.

\section{Scattering layer}

Each radar line shows regions with diffraction hyperbolae about $20-30 \mathrm{~m}$ above the main basal reflector (Fig. 2). Evidence that these features result from sediment inclusions of some type comes from the depths of boreholes since several borehole failures are associated with this depth (Table 1). Possible explanations are that the features are steeply dipping folds, blind thrusts or crevasse fills (e.g. Sharp, 1985a, b). We view thrusting or folding as the most plausible explanation: first, crevasse features are likely to be the product of an extensive deformation regime, rather than of the strongly compressive deformation that has been experienced in this region of the glacier; secondly, the asymmetric form of thrusts or folds would produce diffraction patterns that were also asymmetric, as seen in this region of the data. 128

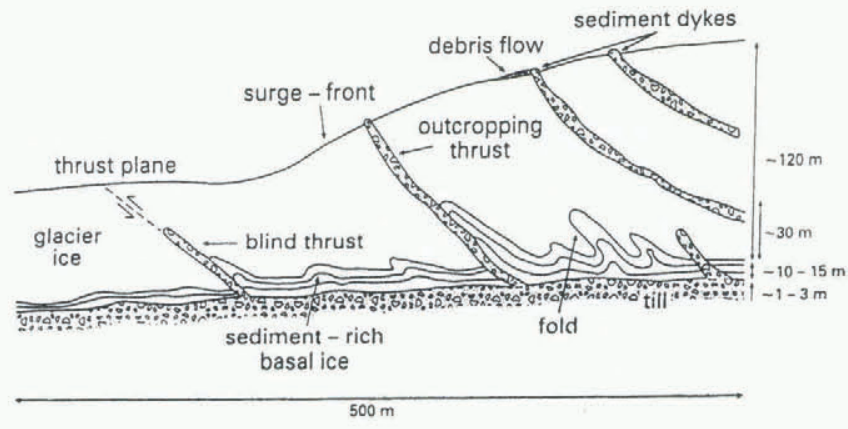

Fig. 6. Schematic interpretation of the main features seen in surveys on the surge front at Bakaninbreen.

\section{GONGLUSIONS}

Several englacial sediment features have been imaged, although there are some surface thrust features which cannot be seen on the GPR survey results, their thickness presumably being below the resolution of the GPR at $100 \mathrm{MHz}$. Figure 6 summarises our interpretation of results from this survey and our drilling programme.

The following conclusions may be drawn:

(1) There is clear potential for the use of commercially available GPR systems in mapping the internal structure of high-Arctic glaciers.

(2) Internal layers have been imaged within the surge front at Bakaninbreen. The two layers in Figure 2 vary in thickness from 0 to $1.1 \mathrm{~m}$, and dip up-glacier at angles of $15-20^{\circ}$. The reflectors can be identified for a distance of approximately $50-60 \mathrm{~m}$, but are intermittent, being composed of sections of $2-10 \mathrm{~m}$ separated by similar length gaps. The debris associated with at least some of these features is basal in origin. We interpret the features as sediment-filled thrust features.

(3) The depth at which boreholes are completed on the survey lines suggests that the cause of a strong reflector at depth is not the glacier bed. This reflector is estimated to lie about 15-20 $\mathrm{m}$ above the bed, and there is no clear reflection at the depth predicted by drilling. The upper surface of the reflector consists of short sections of about $5 \mathrm{~m}$ separated by gaps of similar length. Drilling suggests that there is a considerable amount of sediment associated with this depth in the ice. We have interpreted the reflector as the upper interface of a thick, 15-20 m layer of sediment-rich basal ice at the bed of the glacier. We suggest that this layer is either faulted or folded, and that there is evidence of incipient blind thrusting at its upper surface.

(4) The cause of regions of scattering $10-30 \mathrm{~m}$ above the basal reflector is not entirely clear, but is associated with depths at which boreholes fail, and from which sediment samples have been collected. We have interpreted the features as most likely to be blind-thrust features or folds.

\section{ACKNOWLEDGEMENTS}

Grants from the U.K. Natural Environment Research Council (NERC) (GT3/9031), EU (EN5V-CT93-0299) and Gino Watkins Memorial Fund (Scott Polar Research Institute, Cambridge) funded this research. Purchase of the University of Leeds GPR system was made possible by grants 
from the Academic Development Fund and the School of Geography, University of Leeds. Personal support to D.L.G. was provided by a NERC Advanced Course studentship. We thank the Sysselmann of Svalbard for permission to conduct research at Bakaninbreen. Logistics in the field were made possible by S. Onarheim and F. Olsen of Norsk Polarinstitutt, Oslo, and R. Odegård of Universietsstudiene på Svalbard. A. Hiatt, D. Orton and P. Porter contributed enormously to the success of our field programme.

\section{REFERENGES}

Annan, A. P., W. M. Waller, D.W. Strangway, J. R. Rossiter, J. D. Redman and R. D. Watts. 1975. The electromagnetic response of a low-loss, twolayer, dielectric earth for horizontal electric dipole excitation. Geophysics, $40(2), 285-298$.

Arcone, S. A., D. E. Lawson and A. J. Delaney. 1995. Short-pulse radar wavelet recovery and resolution of dielectric contrasts within englacial and basal ice of Matanuska Glacier, Alaska, U.S.A. J. Glaciol., 41 (137), 68 86.

Bamber, J. L. 1988. Enhanced radar scattering from water inclusions in ice. f. Glaciol., 34(118), 293-296.

Björnsson, H. and 6 others. 1996. The thermal regime of sub-polar glaciers mapped by multi-frequency radio-echo sounding. 7. Glaciol., 42(140), 23- 32.

Bogorodsky, V.V., C. R. Bentley and P. E. Gudmandsen. 1985. Radioglaciology. Dordrecht, etc., D. Reidel Publishing Co.

Clarke, G. K. C. and E. W. Blake. 1991. Geometric and thermal evolution of a surge-type glacier in its quiescent state: Trapridge Glacier, Yukon Territory, Canada, 1969 89. 7. Glaciol., 37(125), 158-169.

Davis, J. L. and A. P. Annan. 1989. Ground-penetrating radar for high-resolution mapping of soil and rock stratigraphy. Geophys. Prospect., 37, 531 551 .

Dowdeswell, J. A., D. J. Drewry, O. Liestøl and O. Orheim. 1984. Radio echo-sounding of Spitsbergen glaciers: problems in the interpretation of layer and bottom returns. F. Glaciol., 30(104), 16-21.

Dowdeswell, J. A., G. S. Hamilton and J. O. Hagen. 1991. The duration of the active phase on surge-type glaciers: contrasts between Svalbard and other regions. f. Glaciol., 37(127), 388-400.

Fischer, U. H. and G. K. C. Clarke. 1994. Ploughing of subglacial sediment. 7. Glaciol., 40 (134), 97-106.

Gooch, D. L. 1995. Geophysical investigation of a glacier surge-front using ground penetrating radar. (M.Sc. thesis, University of Leeds. Department of Earth Sciences.

Hagen, J. O. and A. Sætrang. 1991. Radio-echo soundings of sub-polar glaciers with low-frequency radar. Polar Res., 9(1), 99-107.
Hambrey, M. J. 1994. Glacial environments. London, University College Press. Hambrey, M. J., J. A. Dowdeswell, T. Murray and P. R. Porter. 1996. Thrusting and debris entrainment in a surging glacier: Bakaninbreen, Svalbard. Ann. Glaciol., 22, 241-248.

Jacobel, R.W. and S. K. Anderson. 1987. Interpretation of radio-echo returns from internal water bodies in Variegated Glacier, Alaska, U.S.A. 7. Glaciol., 33 (115), $319-323$.

Jacobel, R. and C. Raymond. 1984. Radio echo-sounding studies of englacial water movement in Variegated Glacier, Alaska. f. Glaciol., 30 (104), $22-29$.

Jones, F. H. M. 1987. Digital impulse radar for glaciology: instrumentation, modelling and field studies. (M.Sc. thesis, University of British Columbia. Department of Geophysics and Astronomy.)

Kamb, B. and 7 others. 1985. Glacier surge mechanism: 1982-1983 surge of Variegated Glacier, Alaska. Science, 227 (4686), 469-479.

Kennett, M. I. 1989. A possible radio-echo method of locating englacial and subglacial waterways. Ann. Glaciol., 13, 135-139.

Lawson, W. J., M. J. Sharp and M. J. Hambrey. 1994. The structural geology of a surge-type glacier. 7. Strucl. Geol., 16(10), 1447-1462.

Macheret, Yu. Ya. and A. B. Zhuravlev. 1982. Radio echo-sounding of Svalbard glaciers. F. Glaciol., 28 (99), 295 314.

Murray, T. and P. R. Porter. 1994. Conditions at the bed of a high-Arctic surging glacier: Bakaninbreen, Svalbard. [Abstract.] EOS, 75 (44), Supplement, 222.

Nicollin, F. and W. Kofman. 1994. Ground penetrating radar sounding of a temperate glacier: modelling of a multilayered medium. Geophys. Prospect., 42 (7), 715-734.

Nobes, D. C., M. P. Hochstein and S. A. Henry. 1994. Ground penetrating radar of rubble-covered glaciers: results from the Tasman and Mueller Glaciers of the Southern Alps of New Zealand. Society of Exploration Geophysicists Annual Meeting. Expanded Abstracts 64, 826829.

Porter, P. R., T. Murray and J. A. Dowdeswell. 1997. Sediment deformation and basal dynamics beneath a glacier surge front: Bakaninbreen, Svalbard. Ann. Glaciol., 24 (see paper in this volume).

Salvigsen, O. and T. S. Winsnes. 1987. Geological map of Svalbard 1:100,000. C10G. Braganzavaigen. Oslo, Norsk Polarinstitutt.

Sensors and Software Inc. 1994. PulseEKKO 100 user's guide version 1.1. Mississauga, Ontario, Sensors and Software Inc. (Technical Manual 25.

Sharp, M. 1985a. "Crevasse-fill" ridges - a landform type characteristic of surging glaciers? Geogr. Ann., 67A (3- 4), 213-220.

Sharp, M. 1985b. Sedimentation and stratigraphy at Eyjabakkajökull - an Icelandic surging glacier. Quat. Res., 24(3), 268- 284.

Sharp, M., W. Lawson and R. S. Anderson. 1988. Tectonic processes in a surge-type glacier. 7. Struct. Geol., 10 (5), $499-515$.

Sharp, M., J. Jouzel, B. Hubbard and W. Lawson. 1994. The character, structure and origin of the basal ice layer of a surge-type glacier. F. Glaciol., 40(135), 327-340.

Walford, M. E. R. and M. I. Kennett. 1989. A synthetic-aperture radio- echo experiment at Storglaciären, Sweden. f. Glaciol., 35(119), 43-47. 